\title{
Effect of different levels of fortification of wheat flour with defatted coconut flour on the quality of fibre-enriched biscuits
}

\author{
J.M.N. Marikkar ${ }^{1 *}$, J.M.M.A. Jayasundara ${ }^{1}$, A.P.D. Rupanjali ${ }^{2}$ and M.N.D. Fernandopulle ${ }^{2}$
}

\begin{abstract}
Defatted coconut flour obtained from the whitish kernel residue left after the extraction of virgin coconut oil has potential application in high protein-fiber enriched food products. A study was conducted to investigate the use of defatted coconut flour in the preparation of fiber-enriched biscuits. In this, wheat flour was fortified with defatted coconut flour in varying proportions $(\mathrm{w} / \mathrm{w}, 0,10,20,30,40,50,60$, and $70 \%$ ) to prepare a series of blends for biscuit dough. Biscuits samples prepared according to a standard recipe were evaluated by a 36-member semi-trained panel using a 7-point hedonic scale to determine the critical limit of defatted coconut flour substitution in wheat flour for acceptable quality biscuits. Results showed that defatted coconut flour could be used to substitute wheat flour up to a level of $40 \%$ without affecting the overall quality. At this level, the dietary fiber content of the biscuit was found to increase by about 10 times. Although biscuit samples showed good acceptability at the beginning, their keeping quality decreased with the increasing level of defatted coconut flour in the biscuit formulation.
\end{abstract}

Key words: Coconut products, defatted coconut flour, dietary fiber, fiber-enriched biscuits.

${ }^{1}$ Coconut Research Institute, Lunuwila, Sri Lanka and ${ }^{2}$ Department of Plantation Management, Wayamba University of Sri Lanka, Makandura, Gonawila, Sri Lanka. 


\section{Introduction}

Coconut oil extraction is an important industry in many countries in Asia and the Pacific region. There are a number of technologies for extraction of coconut oil. These technologies can be categorized broadly into either aqueous or dry processing methods. In the aqueous extraction process, coconut milk is taken out of the kernel, which is subsequently converted into coconut oil. On the other hand, the dry process involves the conversion of coconut meat into copra which is then fed into oil expellers for oil extraction. The defatted oil cake left after the oil extraction is an important byproduct. Its quality can be varied depending on the processing technique. Since the commercial oil expellers are operated under high temperature conditions, the oil cake coming out of the expeller is found to be burnt and undergone various chemical changes. As a result it is poor in quality and not suitable as a feedstock for human consumption. However, the recently introduced technology for virgin coconut oil extraction has many advantages over the traditional method of coconut oil production. Since this technology operates at low temperature heating, the oil cake coming out of the expeller is not severely burnt or undergone any thermal degradation. Therefore, the defatted kernel residue looks whitish in color and its carbohydrates and proteins are preserved from any damages. The carbohydrate part of the defatted kernel residue is composed of a portion of soluble sugars and non soluble fibrous materials. The fibrous component of the kernel residue is of a particular interest due to the beneficial health effects. According to previous reports, endogenous secretions of the human dietary track do not degrade dietary fiber and, therefore, the major beneficial effects of the fibre are its bulking capacity, and the water-holding capacity which ultimately facilitates the prevention of constipation (de Man, 1990).

As a source of dietary fiber, DCF can also provide many other health benefits particularly in relation to coronary artery diseases, cancer, and diabetic millet. Past studies have indicated that coconut flour may reduce the concentration of cholesterol in blood (Aroncon, 1999). Apart from this, a study reported by Trinidad et al (2003) showed that the glycemic indexes of bakery food products were found to be lowered when coconut flour was incorporated. These reports highlighted the potential of defatted coconut flour as a source of food for people with special dietary requirements. With the current nutritional trend, people are more concerned about their health and the nutritional status of their diet. Consumers look for more nutritious and ready-to-eat convenient products with good keeping quality and a satisfactory taste (Mbofung et al, 2002). Bakery products like biscuits could easily satisfy these requirements (Chavan and Kadam, 1999). Generally snack products like biscuits are preferred by people of all ages, ethnicity and cultures throughout the world. In the preparation of fiber-enriched biscuits for special dietary requirement, the defatted coconut flour could be ideally suited due to the above nutritional values and various health benefits. However, the level of incorporation of DCF in biscuit formulation has to be determined on the basis of sensory evaluation study. Therefore, this study was undertaken to investigate the consumer acceptable limits of defatted coconut flour incorporation in biscuits and determine the proximate composition and the storage stability of the fiber-enriched biscuits.

\section{Materials and methods}

\section{Biscuit baking}

A standard dough formulation, shown in Table 1, was used for biscuit baking. A commercially milled bread wheat flour (WF) sample was obtained from Prima Ceylon Co Ltd. A sample of defatted coconut flour (DCF) was obtained from the virgin coconut oil production facility of the Coconut Research Institute. Wheat flour (WE) and DCF were weighed separately and mixed in differing proportions. A total of eight treatments (mixtures) were prepared, $\mathrm{T}_{0^{-}}$0:100, $\mathrm{T}_{1^{-}}$10:90, $\mathrm{T}_{2^{-}}$20:80, $\mathrm{T}_{3^{-}}$30:70, $\mathrm{T}_{4^{-}}$40:60, $\mathrm{T}_{5^{-}}$50:50, $\mathrm{T}_{6^{-}}$ $60: 40, \mathrm{~T}_{7}-70: 30,(\mathrm{w} / \mathrm{w})$ and identified by the mass ratio of DCF to WF. The biscuits were prepared by first creaming margarine, sugar and 
egg to a smooth whitish soft paste using a mixer and then mixing with DCF, wheat flour and baking power with appropriate quantities. The resulting dough was kneaded gently and rolled out to a thickness of about $0.5 \mathrm{~cm}$. After cutting the thin sheet of dough into circular pieces of 5.0 $\mathrm{cm}$ diameter using a round cutter, samples were baked at $180^{\circ} \mathrm{C}$ for 20 minutes. After taking out of the oven, the biscuit samples were allowed to cool before packing.

\section{Sensory evaluation}

\section{Ranking test}

This is a performance test and is done to rank the samples according to the preference of a thirty-six member semi-trained panelists. Panelists were asked to rank eight coded samples according to the intensity of overall quality (appearance, texture, taste, smell \& overall acceptability) of biscuits.

\section{Testing criteria}

A seven point Hedonic scale (1: dislike very much; 2: dislike; 3: dislike slightly; 4: neither like nor dislike; 5: like slightly; 6: like; 7: like very much) was used to evaluate degree of liking for each sensory attribute.

\section{Statistical analysis}

Results of sensory evaluation were analyzed using non-parametric Friedman rank sum test in the Minitab software package version 14.00 (SAS 1998).

\section{Proximate Compositional Analysis of Biscuit Samples}

For analysis purpose, biscuit samples were ground into powders using mortar and pestle. Moisture content was determined using oven (Gallenkamp, SANYO Gallenkamp PLC, U.K.) method by drying at $105^{\circ} \mathrm{C}$ for $4 \mathrm{hrs}$ and then to constant weight (SLS 251: 1991); Oil content was determined by soxhlet extraction using petroleum ether $\left(40-60{ }^{\circ} \mathrm{C}\right)$ as solvent (Pearson, 1973); mineral content determination was by dry ashing method (Pearson, 1973); crude protein content determination by micro Kjeldahl method (AOAC, 1999); crude fiber content determination by Weende method (AOAC, 1999) and total sugar content determination by phenol-sulfuric acid method (Bemiller and Low, 1998).

\section{Gas Liquid Chromatographic (GLC) Analysis of Fatty Acid Methyl Esters (FAME)}

FAME were prepared by dissolving oil sample $(50 \mathrm{mg})$ with petroleum ether $(0.8 \mathrm{ml})$ and sodium methoxide (1M, $0.2 \mathrm{ml}$ ) (PORIM Test Methods, 1995) and analyzed (in duplicate) on a gas chromatograph (Agillent 4890D GC system, Agillent Technologies, Singapore) fitted with a Flame Ionization Detector (FID). A nonpolar capillary column HP-5 MS $(0.25 \mathrm{~mm}$ internal diameter, $30 \mathrm{~m}$ length and $0.25 \mu \mathrm{m}$ film thickness, Hewlett Packard Company, Singapore) was used at a column pressure of 10 bars. The initial temperature of the column was at $100^{\circ} \mathrm{C}$ and was programmed to increase to $220^{\circ} \mathrm{C}$ at $4{ }^{\circ} \mathrm{C} / \mathrm{min}$ and kept for $15 \mathrm{~min}$ at $220^{\circ} \mathrm{C}$. The temperatures of the injector and detector were maintained at $250^{\circ} \mathrm{C}$ and $275^{\circ} \mathrm{C}$, respectively. Standard methyl esters of fatty acids were used as authentic samples and comparing relative retention times did peak identification. The percentage of individual fatty acid was determined by rationing the partial area to the total peak area (Marikkar et al., 2006).

\section{Shelf life studies}

For storability test, biscuit samples were packed under hygienic condition in clean packages and sealed immediately to protect product quality. For the purpose of packaging, low-density polyethylene (LDPE) bags were used. Sample bags were kept at room temperature $\left(27^{\circ} \mathrm{C}\right.$ and $\left.\mathrm{RH} 60 \%\right)$ until the analyses were performed. Analyses for shelf life studies were done once in two weeks for a 
period of three months. Oils of biscuit samples were extracted by soxhlet extraction procedure using petroleum ether $\left(40-60^{\circ} \mathrm{C}\right)$ as solvent (Pearson, 1973). PV of oil was determined by dissolving oil sample $(5 \mathrm{~g})$ in acetic acidchloroform solution and titrated with $0.01 \mathrm{~N}$ sodium thiosulphate in the presence of saturated potassium iodide using starch as indicator (PORIM Test Methods, 1995). Free fatty acid content of oil sample $(5 \mathrm{~g})$ was determined by dissolving the sample in $95 \%$ ethyl alcohol followed by titration with $0.1 \mathrm{~N}$ sodium hydroxide using phenolphthalein as indicator (AOCS, 1987).

\section{Microbiological analysis}

Enumeration of aerobic colony count was done by incubating micro-organisms in nutrient agar (NA) medium under $37^{\circ} \mathrm{C}$ for 48 hours and the yeast and mould count was done by incubating in potato dextrose agar (PDA) medium with $0.01 \%$ Chloramphenicol held at room temperature (SLS 516:1991).

\section{Results and discussion}

In biscuit formulation, the main ingredient is usually wheat flour which is reported to contain low amount of total dietary fibre (Leelavathi and Rao, 1993). According to recent reports, DCF is a source rich in both soluble and non-soluble carbohydrates and fairly a higher amount of vegetable proteins. It was found to possess fibre components such as crude fibre (CF), neutral detergent fibre (NDF), acid detergent fibre (ADF), hemicellulose, and cellulose (Yalegama and Chavan, 2006). Therefore, supplementation of wheat flour with DCF could not only increase fiber content, but also it could substantially increase the amounts of proteins which can supplement the protein content of biscuits. In addition to theses, the higher sugar content of DCF could help reduce the amount of sugar to be added into the biscuit formulation. Hence the benefits of fortification of wheat flour with DCF are worthwhile for consideration.

\section{Biscuit Formulation and Dough Consistency}

The main focus of the study was to look into the effect of incorporation of the DCF on the quality and consistency of dough. According to Table 1, the formulation contained margarine, sugar, baking powder and egg as ingredients and their added quantities were kept constant. The practical experience showed that the control and the blends up to $30 \%$ DCF level were able to produce dough with good consistency with the availability of water from eggs. However, when the portion of DCF increased beyond $30 \%$, dough was found to be sticky and its handling became increasingly difficult. Therefore, a portion of water had to be added to the formulations containing higher than $30 \%$ DCF. In fact, the increasing water requirement at higher levels of fortification could be due to the increasing proportion of non-soluble carbohydrates in the fortified blends. The water holding capacity of non-soluble carbohydrates is already an established fact. Further, the replacement of wheat flour with DCF was also found to bring about a considerable increase in dough weight which subsequently increased the yield of biscuit as shown in Table 2. Although the quantitative yield of biscuits increased, it was necessary to pay attention to the effect of supplementation on the sensory attributes of the

\section{Table 1. Recipe of Biscuit Formulation for Different Treatments ${ }^{1}$}




\begin{tabular}{|c|c|c|c|c|c|c|c|}
\hline Treatment & $\begin{array}{c}\text { Wheat } \\
\text { flour }(\mathbf{g})\end{array}$ & $\begin{array}{c}\text { Coconut } \\
\text { flour }(\mathbf{g})\end{array}$ & $\begin{array}{c}\text { Margarine } \\
\mathbf{( g )}\end{array}$ & Sugar (g) & $\begin{array}{c}\text { Baking } \\
\text { Powder }(\mathbf{g})\end{array}$ & Egg (g) & Water (g) \\
\hline $\mathrm{To}_{0}$ & 500 & 0 & 250 & 200 & 20 & 80 & 0 \\
\hline $\mathrm{T}_{1}$ & 450 & 50 & 250 & 200 & 20 & 80 & 0 \\
\hline $\mathrm{T}_{2}$ & 400 & 100 & 250 & 200 & 20 & 80 & 0 \\
\hline $\mathrm{T}_{3}$ & 350 & 150 & 250 & 200 & 20 & 80 & 0 \\
\hline $\mathrm{T}_{4}$ & 300 & 200 & 250 & 200 & 20 & 80 & 100 \\
\hline $\mathrm{T}_{5}$ & 250 & 250 & 250 & 200 & 20 & 80 & 200 \\
\hline $\mathrm{T}_{6}$ & 200 & 300 & 250 & 200 & 20 & 80 & 250 \\
\hline $\mathrm{T}_{7}$ & 150 & 350 & 250 & 200 & 20 & 80 & 300 \\
\hline
\end{tabular}

${ }^{1}$ Abbreviations: $\mathrm{T}_{0}$, biscuit formulation by wheat flour; $\mathrm{T}_{1}$, biscuit formulation by wheat flour mixed with $10 \%$ defatted coconut flour (DCF); $\mathrm{T}_{2}$, biscuit formulation by wheat mixed with $20 \% \mathrm{DCF} ; \mathrm{T}_{3}$, biscuit formulation by wheat mixed with $30 \% \mathrm{DCF} ; \mathrm{T}_{4}$, biscuit formulation by wheat flour mixed with $40 \% \mathrm{DCF} ; \mathrm{T}_{5}$, biscuit formulation by wheat flour mixed with $50 \%$ DCF; $\mathrm{T}_{6}$, biscuit formulation by wheat flour mixed with $60 \% \mathrm{DCF} ; \mathrm{T}_{7}$, biscuit formulation by wheat mixed with $70 \%$ DCF.

Table 2. Comparison of biscuit weight and dough weight ${ }^{1}$

\begin{tabular}{ccc}
\hline Treatment & Dough Weight $(\mathbf{g})$ & Biscuit Yield $(\mathbf{g})$ \\
\hline $\mathrm{T}_{0}$ & 988.2 & 849.5 \\
$\mathrm{~T}_{1}$ & 1008.1 & 873.1 \\
$\mathrm{~T}_{2}$ & 1040.6 & 881.0 \\
$\mathrm{~T}_{3}$ & 1095.5 & 884.3 \\
$\mathrm{~T}_{4}$ & 1155.3 & 887.3 \\
\hline
\end{tabular}

${ }^{1}$ Each value in the table represents the mean of duplicate trials.

Abbreviations: See Table 1.

finished products, which may help to determine the critical limit of fortification of wheat flour with DCF. For this purpose, a scientific-based sensory evaluation was needed to be performed.

\section{Sensory Evaluation}

Sensory attributes such as appearance, smell or aroma, taste and texture are good indicators of consumer acceptance of biscuits. 
According to a previous report, utilization of the defatted kernel residue in bakery products had an upper limit of 20\% incorporation (Banzon and Velasco, 1982). Similarly, another study involving some Indian food preparations recommended a $20 \%$ addition of DCF for wheat flour-based products while only a $10 \%$ supplementation for rice flour-based foods. In these studies, the process of obtaining the DCF involved the defatting of the kernel residue followed by a solvent extraction step (Banzon and Velasco, 1982) or made use of the residue left after the aqueous extraction of milk out of the fresh coconut kernel (Ramaswamy, 2006). It should be noted that the quality of the DCF could be varied based on the process of production. Hence, the changing proportion of DCF in different formulations could be either due to the change in the quality of DCF or the nature food items concerned. However, in the present study, the source of DCF was defatted kernel residue which was not subjected to any physical or chemical treatments. Hence, its physical appearance and organoleptic characteristics were better than those of the ordinary defatted kernel residue.

In the determination of the critical limit of fortification, it is also important to adopt proper methods of sensory evaluation and statistics. In this study, it appeared that the different levels of wheat flour substitution with DCF did not have any direct impact on the appearance and smell characters of biscuits. According to Friedman test for the sensory attributes data presented in Table 3 , there was no significant difference between the control and the different levels of DCF incorporated samples with respect to appearance and smell. However, attributes such as taste, texture, and overall acceptability were seemed to be more sensitive to the changing proportion of DCF in the flour component. With regard to these three sensory characteristics, there was no significant difference between the control and the DCF substituted biscuit samples up to the level of $40 \%$ substitution (Table 3). Nevertheless, a slight gritty taste and undesirable mouth-feel were observed by the panelists in biscuit samples containing DCF level exceeding $40 \%$. Hence, it can be confirmed that a $40 \%$ incorporation of DCF with wheat flour could be possible in the formulation of acceptable quality biscuits. Therefore, it was decided to limit the DCF substitution up to $40 \%$ and compositional analyses and storage studies were carried out only for biscuit samples made out of flour mixtures containing 0,10, 20, 30 and 40\% DCF supplementation.

\section{Proximate Composition of Biscuit Samples}

Proximate compositions of biscuit samples prepared out of different levels of supplemetation are compared with those of the control as shown in Table 4. When compared with the control, samples made out of wheat flour/DCF blends showed significant increases $(\mathrm{p}<0.0001)$ with respect to moisture and ash contents. While the increase in ash content was a positive indication of enrichment, the increase in moisture was a bit of a concern for storability. The increase in moisture content may be due to the increased water holding capacity of biscuit samples caused by the fortification. Although the moisture values are within the ranges found in market available samples (Awasthi and Yadav, 2000), the increasing moisture content seemed to have affected the texture or crispness of the biscuits. According to the statistical analysis of data presented in Table 3, there was a decreasing trend in the sum of ranks recorded for textural characteristics. This seems to suggest that

\section{Table 3. Results of Friedman test along with sum of ranks of sensory attributes of different treatments ${ }^{1}$}

\begin{tabular}{|c|c|c|c|c|c|}
\hline Treatment & Appearance & Texture & Taste & Smell & $\begin{array}{c}\text { Overall } \\
\text { acceptability }\end{array}$ \\
\hline $\mathrm{T}_{0}$ & $164.0^{\mathrm{a}}$ & $197.0^{\mathrm{a}}$ & $196.0^{\mathrm{a}}$ & $154.5^{\mathrm{a}}$ & $178.5^{\mathrm{a}}$ \\
\hline
\end{tabular}




\begin{tabular}{|c|c|c|c|c|c|}
\hline $\mathrm{T}_{1}$ & $170.0^{\mathrm{a}}$ & $200.5^{\mathrm{a}}$ & $212.0^{\mathrm{a}}$ & $169.5^{\mathrm{a}}$ & $184.5^{\mathrm{a}}$ \\
\hline $\mathrm{T}_{2}$ & $160.5^{\mathrm{a}}$ & $195.0^{\mathrm{a}}$ & $204.0^{\mathrm{a}}$ & $195.5^{\mathrm{a}}$ & $173.5^{\mathrm{a}}$ \\
\hline $\mathrm{T}_{3}$ & $185.0^{\mathrm{a}}$ & $195.0^{\mathrm{a}}$ & $189.0^{\mathrm{a}}$ & $174.0^{\mathrm{a}}$ & $180.5^{\mathrm{a}}$ \\
\hline $\mathrm{T}_{4}$ & $192.0^{\mathrm{a}}$ & $170.5^{\mathrm{a}, \mathrm{b}}$ & $176.0^{\mathrm{a}, \mathrm{b}}$ & $175.0^{\mathrm{a}}$ & $158.0^{\mathrm{a}, \mathrm{b}}$ \\
\hline $\mathrm{T}_{5}$ & $136.0^{\mathrm{a}}$ & $128.0^{\mathrm{b}, \mathrm{c}}$ & $111.5^{\mathrm{b}}$ & $136.0^{\mathrm{a}}$ & $110.0^{\mathrm{b}}$ \\
\hline $\mathrm{T}_{6}$ & $132.5^{\mathrm{a}}$ & $99.5^{\mathrm{b}, \mathrm{c}}$ & $99.0^{\mathrm{b}}$ & $138.0^{\mathrm{a}}$ & $100.5^{\mathrm{b}}$ \\
\hline $\mathrm{T}_{7}$ & $156.0^{\mathrm{a}}$ & $110.5^{\mathrm{c}}$ & $108.0^{\mathrm{b}}$ & $153.5^{\mathrm{a}}$ & $102.5^{\mathrm{b}}$ \\
\hline $\begin{array}{c}\text { Treatment } \\
\text { wise CL }\end{array}$ & $\mathrm{ns}$ & $* * *$ & $* * *$ & $\mathrm{~ns}$ & $* * *$ \\
\hline
\end{tabular}

${ }^{1}$ Means in the same column bearing different superscripts are significantly different from each other. Abbreviations: CL, Confidence level; ns, not significant; ***p<0.0001. For other abbreviations see Table 1.

Table 4. Proximate composition of biscuit samples out of different treatments
(g/100 g dry matter basis $)^{1}$

\begin{tabular}{|c|c|c|c|c|c|c|c|}
\hline Treatment & Moisture & Ash & Protein & Fat & $\begin{array}{c}\text { Crude } \\
\text { Fiber }\end{array}$ & $\begin{array}{c}\text { Soluble } \\
\text { Sugar }\end{array}$ & $\begin{array}{c}\text { Other } \\
\text { Carbohydrates } \\
\text { (by difference) }\end{array}$ \\
\hline $\mathrm{T}_{0}$ & $1.72^{\mathrm{a}}$ & $1.49^{\mathrm{a}}$ & $5.93^{\mathrm{a}}$ & $20.82^{\mathrm{a}}$ & $0.60^{\mathrm{a}}$ & $24.66^{\mathrm{a}}$ & $44.77^{\mathrm{a}}$ \\
\hline $\mathrm{T}_{1}$ & $2.06^{\mathrm{b}}$ & $1.67^{\mathrm{b}}$ & $8.31^{\mathrm{b}}$ & $22.46^{\mathrm{b}}$ & $2.50^{\mathrm{b}}$ & $27.86^{\mathrm{a}}$ & $35.15^{\mathrm{a}, \mathrm{b}}$ \\
\hline $\mathrm{T}_{2}$ & $2.34^{\mathrm{c}}$ & $1.99^{\mathrm{c}}$ & $8.99^{\mathrm{b}}$ & $22.93^{\mathrm{b}}$ & $3.65^{\mathrm{c}}$ & $28.35^{\mathrm{a}}$ & $31.74^{\mathrm{b}}$ \\
\hline $\mathrm{T}_{3}$ & $2.58^{\mathrm{c}}$ & $2.19^{\mathrm{d}}$ & $10.80^{\mathrm{c}}$ & $23.70^{\mathrm{c}}$ & $5.30^{\mathrm{d}}$ & $30.84^{\mathrm{a}}$ & $24.60^{\mathrm{b}, \mathrm{c}}$ \\
\hline $\mathrm{T}_{4}$ & $3.02^{\mathrm{d}}$ & $2.44^{\mathrm{e}}$ & $12.36^{\mathrm{c}}$ & $24.90^{\mathrm{d}}$ & $6.10^{\mathrm{e}}$ & $32.29^{\mathrm{a}}$ & $18.88^{\mathrm{c}}$ \\
\hline Significance & $* * *$ & $* * *$ & $* *$ & $* * *$ & $* * *$ & $\mathrm{~ns}$ & $*$ \\
\hline
\end{tabular}

${ }^{1}$ Means in the same column bearing different letters are significantly different from each other. Abbreviations: ns, not significant; $*(\mathrm{p}<0.05) ; * *(\mathrm{p}<0.001) ; * * *(\mathrm{p}<0.0001)$. For other abbreviations see Table 1.

limiting of the quantity of added water into the formulation would be a better option.

According to the data presented in Table 4, there were significant increases $(p<0.001)$ in fat and protein contents of the biscuit samples when compared to the control. According to our previous reports, DCF is a low-fat but high protein material having about $20 \%$ protein and $12.0 \%$ fat on a dry basis (Beansch et al, 2004).
Since these values are higher than those reported for commercially milled wheat flour which contains $10.33 \%$ proteins and $0.98 \%$ fat (USDA, 2005), fortification definitely helps to raise the protein and fat contents of biscuit samples.

In any biscuit formulation, soluble sugars have an important role in determining the taste and color of the finished products. Although 
there were notable differences in the values of soluble sugar contents between the control and DCF-fortified biscuit samples, the difference was statistically non-significant. However, between the control and DCF-fortified samples, other carbohydrates content was found to decrease significantly $(p<0.02)$ while there was a significant increase in crude fiber content $(\mathrm{p}<0.01)$ (Table 4).

\section{Fatty acid Profile of Biscuit Samples}

Margarine and shortening has a role to play in bakery products. Generally, the choice of oil or fat may vary depending on the type of application and properties desired. In this study, margarine was the source of fat for biscuit preparation. According to the FAME analysis data presented in Table 5, palmitic and oleic acids were detected as predominating fatty acids in the oils extracted from the biscuit samples. This suggests as if the margarine were formulated out of palm oil (Swe et al, 1995; Ong et al, 1995). With the supplementation of DCF, the fatty acid profile of all the treatments seemed to have been affected. Probably, this may be due to the increase of the coconut oil component in the finished products with the increasing level of DCF in the dough mixture. As could be seen from the Table 5, the proportion of short and medium chain fatty acids increased from $0.4 \%$ in the control to $4.5 \%$ in the $40 \%$ substitution level.

\section{Storability of Biscuit Samples}

Keeping quality of any food item may be affected with time and thereby its sensory characteristics such as taste, smell, color, and texture can be deteriorated. When considering the keeping quality of food materials, initial moisture content, storage temperature and packaging material are key factors. For the purpose of monitoring the keeping quality of biscuit samples, it is necessary to determine moisture, free fatty acid content, peroxide value etc. as parameters. Particularly, moisture absorption is a critical factor, which might affect the long-term storability of biscuits. According to the data presented in Table 6, moisture content of the control and DCFfortified samples tended to increase slightly with time. Nevertheless, during the entire storage period, none of these samples exceeded the $6 \%$ upper limit for moisture content specified by the standardization agencies (SLS 251:1991; BIS 1974). The changes in free fatty acid content and peroxide values of the biscuit samples during the storage are also shown in Table 6. In almost all samples, only a slight variation could be noticed with regard to these two parameters. However, non of the samples showed any off-flavor or taste development during the three months storage period.

When considering storability of biscuits, microbiological quality is another important factor and therefore, it is very necessary to monitor the growth of micro flora during storage. According to food microbiological criteria tables, aerobic plate count (APC) and yeast and mould count (YMC) of plain / simple biscuits should not exceed $1 \times 10^{3}$ and $1 \times 10^{2}$, respectively (Shapton and Shapton, 1998). In

Table 5. Distribution of fatty acids (area \%) of biscuits out of different treatments ${ }^{1}$

${ }^{1}$ Each value in the table represents the mean of duplicate analyses. Abbreviations: See Table 1. 


\begin{tabular}{|c|c|c|c|c|c|c|c|c|}
\hline \multirow{2}{*}{ Treatment } & \multicolumn{7}{|c|}{ Fatty acid } \\
\cline { 2 - 9 } & $\begin{array}{c}\text { Caprylic } \\
(\mathbf{C 8 : 0 )}\end{array}$ & $\begin{array}{c}\text { Capric } \\
(\mathbf{C 1 0 : 0 )}\end{array}$ & $\begin{array}{c}\text { Lauric } \\
(\mathbf{C 1 2 : 0})\end{array}$ & $\begin{array}{c}\text { Myristic } \\
(\mathbf{C 1 4 : 0 )}\end{array}$ & $\begin{array}{c}\text { Palmitic } \\
(\mathbf{C 1 6 : 0 )}\end{array}$ & $\begin{array}{c}\text { Oleic } \\
(\mathbf{C 1 8 : 1 )}\end{array}$ & $\begin{array}{c}\text { Linoleic } \\
(\mathbf{C 1 8 : 2})\end{array}$ & Unknowns \\
\hline $\mathrm{T}_{0}$ & 0.05 & 0.00 & 0.35 & 1.02 & 55.06 & 37.66 & 5.72 & 0.13 \\
\hline $\mathrm{T}_{1}$ & 0.14 & 0.16 & 0.96 & 1.28 & 54.63 & 37.20 & 5.48 & 0.14 \\
\hline $\mathrm{T}_{2}$ & 0.22 & 0.17 & 1.76 & 1.61 & 54.20 & 36.50 & 5.44 & 0.10 \\
\hline $\mathrm{T}_{3}$ & 0.31 & 0.25 & 2.69 & 1.96 & 53.24 & 36.05 & 5.39 & 0.10 \\
\hline $\mathrm{T}_{4}$ & 0.50 & 0.38 & 3.63 & 2.36 & 52.19 & 35.45 & 5.37 & 0.10 \\
\hline
\end{tabular}

Table 6. Changes in moisture, free fatty acid, and peroxide value of biscuit samples with time ${ }^{1}$

\begin{tabular}{|c|c|c|c|c|c|c|c|}
\hline \multirow[t]{2}{*}{ Treatment } & \multicolumn{7}{|c|}{ Time (weeks) } \\
\hline & $\mathbf{0}$ & 2 & 4 & 6 & 8 & 10 & 12 \\
\hline \multicolumn{8}{|c|}{ Moisture (\%) } \\
\hline $\mathrm{T}_{0}$ & $1.72^{\mathrm{a}}$ & $2.95^{\mathrm{b}}$ & $3.18^{\mathrm{c}}$ & $3.48^{\mathrm{d}}$ & $3.89^{\mathrm{e}}$ & $4.61^{\mathrm{f}}$ & $5.50^{\mathrm{g}}$ \\
\hline $\mathrm{T}_{1}$ & $2.06^{\mathrm{a}}$ & $2.72^{\mathrm{b}}$ & $2.97^{\mathrm{b}}$ & $3.65^{\mathrm{c}}$ & $4.16^{\mathrm{d}}$ & $4.44^{\mathrm{d}}$ & $5.43^{\mathrm{e}}$ \\
\hline $\mathrm{T}_{2}$ & $2.34^{\mathrm{a}}$ & $2.58^{\mathrm{b}}$ & $2.86^{\mathrm{c}}$ & $3.28^{\mathrm{d}}$ & $3.71^{\mathrm{e}}$ & $3.81^{\mathrm{e}}$ & $4.14^{\mathrm{f}}$ \\
\hline $\mathrm{T}_{3}$ & $2.58^{\mathrm{a}}$ & $2.87^{\mathrm{b}}$ & $3.21^{\mathrm{c}}$ & $3.86^{\mathrm{d}}$ & $4.16^{\mathrm{e}}$ & $4.88^{\mathrm{f}}$ & $5.10^{\mathrm{f}}$ \\
\hline $\mathrm{T}_{4}$ & $3.02^{\mathrm{a}}$ & $3.13^{\mathrm{a}}$ & $3.32^{\mathrm{a}}$ & $3.87^{\mathrm{b}}$ & $4.21^{\mathrm{c}}$ & $5.23^{\mathrm{d}}$ & $5.64^{\mathrm{e}}$ \\
\hline \multicolumn{8}{|c|}{ Free fatty acids ( $\%$ palmitic) } \\
\hline $\mathrm{T}_{0}$ & $0.24^{\mathrm{a}}$ & $0.28^{\mathrm{a}}$ & $0.42^{\mathrm{b}}$ & $0.54^{\mathrm{c}}$ & $0.58^{\mathrm{d}}$ & $0.64^{\mathrm{e}}$ & $0.78^{\mathrm{f}}$ \\
\hline $\mathrm{T}_{1}$ & $0.26^{\mathrm{a}}$ & $0.30^{\mathrm{b}}$ & $0.43^{\mathrm{c}}$ & $0.58^{\mathrm{d}}$ & $0.61^{\mathrm{e}}$ & $0.66^{\mathrm{f}}$ & $0.79^{\mathrm{g}}$ \\
\hline $\mathrm{T}_{2}$ & $0.33^{\mathrm{a}}$ & $0.34^{\mathrm{a}}$ & $0.44^{\mathrm{b}}$ & $0.59^{\mathrm{c}}$ & $0.62^{\mathrm{c}}$ & $0.69^{\mathrm{d}}$ & $0.81^{\mathrm{e}}$ \\
\hline $\mathrm{T}_{3}$ & $0.34^{\mathrm{a}}$ & $0.42^{\mathrm{b}}$ & $0.50^{\mathrm{c}}$ & $0.63^{\mathrm{d}}$ & $0.66^{\mathrm{d}}$ & $0.75^{\mathrm{e}}$ & $0.84^{\mathrm{f}}$ \\
\hline $\mathrm{T}_{4}$ & $0.34^{\mathrm{a}}$ & $0.48^{\mathrm{b}}$ & $0.52^{\mathrm{b}}$ & $0.64^{\mathrm{c}}$ & $0.70^{\mathrm{d}}$ & $0.78^{\mathrm{e}}$ & $0.86^{\mathrm{f}}$ \\
\hline \multicolumn{8}{|c|}{ Peroxide value (meq/kg) } \\
\hline $\mathrm{T}_{0}$ & $1.49^{\mathrm{a}}$ & $3.00^{\mathrm{b}}$ & $4.26^{\mathrm{c}}$ & $6.88^{\mathrm{d}}$ & $8.56^{\mathrm{e}}$ & $9.88^{\mathrm{f}}$ & $12.51^{\mathrm{g}}$ \\
\hline $\mathrm{T}_{1}$ & $1.99^{\mathrm{a}}$ & $4.18^{\mathrm{b}}$ & $4.30^{\mathrm{b}}$ & $7.21^{\mathrm{c}}$ & $9.37^{\mathrm{d}}$ & $10.90^{\mathrm{e}}$ & $11.96^{t}$ \\
\hline $\mathrm{T}_{2}$ & $2.99^{\mathrm{a}}$ & $4.31^{\mathrm{b}}$ & $4.42^{\mathrm{b}}$ & $7.76^{\mathrm{c}}$ & $9.49^{\mathrm{d}}$ & $10.50^{\mathrm{e}}$ & $11.46^{\mathrm{t}}$ \\
\hline $\mathrm{T}_{3}$ & $3.99^{\mathrm{a}}$ & $4.68^{\mathrm{b}}$ & $5.08^{\mathrm{c}}$ & $8.18^{\mathrm{d}}$ & $9.78^{\mathrm{e}}$ & $11.25^{\mathrm{f}}$ & $12.58^{\mathrm{s}}$ \\
\hline $\mathrm{T}_{4}$ & $4.42^{\mathrm{a}}$ & $4.99^{\mathrm{b}}$ & $5.31^{\mathrm{c}}$ & $8.50^{\mathrm{d}}$ & $10.62^{\mathrm{e}}$ & $11.02^{\mathrm{f}}$ & $12.92^{\mathrm{s}}$ \\
\hline
\end{tabular}

${ }^{1}$ Each value in the table represents the mean of duplicate analyses. Abbreviations: See Table 1.

Table 7. Changes in aerobic plate count and yeast and mould count of biscuit samples with time ${ }^{1}$ 


\begin{tabular}{|c|c|c|c|c|c|c|c|}
\hline Treatment & $\mathbf{0}$ & $\mathbf{2}$ & $\mathbf{4}$ & $\mathbf{6}$ & $\mathbf{8}$ & $\mathbf{1 0}$ & $\mathbf{1 2}$ \\
\hline \multicolumn{7}{|c|}{ Aerobic plate count $(\mathbf{C F U} / g)$} \\
\hline \multicolumn{7}{|c|}{ Yeast and mould count $(\mathbf{C F U} / \mathbf{g})$} \\
\hline $\mathrm{T}_{0}$ & $4.51 \times 0^{2 \mathrm{a}}$ & $5.35 \times 10^{3 \mathrm{~b}}$ & $1.05 \times 10^{4 \mathrm{c}}$ & $1.75 \times 10^{4 \mathrm{~d}}$ & $2.55 \times 10^{4 \mathrm{f}}$ & $3.10 \times 10^{4 \mathrm{f}}$ & $3.75 \times 10^{4 \mathrm{~g}}$ \\
\hline $\mathrm{T}_{1}$ & $4.30 \times 10^{2 \mathrm{a}}$ & $5.15 \times 10^{3 \mathrm{~b}}$ & $9.75 \times 10^{3 \mathrm{c}}$ & $1.60 \times 10^{4 \mathrm{~d}}$ & $2.10 \times 10^{4 \mathrm{e}}$ & $2.60 \times 10^{4 \mathrm{f}}$ & $3.25 \times 10^{4 \mathrm{~g}}$ \\
\hline $\mathrm{T}_{2}$ & $3.85 \times 10^{2 \mathrm{a}}$ & $5.15 \times 10^{2 \mathrm{~b}}$ & $9.40 \times 10^{3 \mathrm{c}}$ & $1.50 \times 10^{4 \mathrm{~d}}$ & $2.20 \times 10^{4 \mathrm{e}}$ & $2.60 \times 10^{4 \mathrm{f}}$ & $3.45 \times 10^{4 \mathrm{~g}}$ \\
\hline $\mathrm{T}_{3}$ & $3.95 \times 10^{2 \mathrm{a}}$ & $4.90 \times 10^{3 \mathrm{~b}}$ & $9.45 \times 10^{3 \mathrm{c}}$ & $1.40 \times 10^{4 \mathrm{~d}}$ & $1.85 \times 10^{4 \mathrm{e}}$ & $2.40 \times 10^{4 \mathrm{f}}$ & $3.55 \times 10^{4 \mathrm{~g}}$ \\
\hline $\mathrm{T}_{4}$ & $3.90 \times 10^{2 \mathrm{a}}$ & $4.75 \times 10^{3 \mathrm{~b}}$ & $9.10 \times 10^{3 \mathrm{c}}$ & $1.25 \times 10^{4 \mathrm{~d}}$ & $1.80 \times 10^{4 \mathrm{e}}$ & $2.10 \times 10^{4 \mathrm{f}}$ & $3.05 \times 10^{4 \mathrm{~g}}$ \\
\hline \multicolumn{7}{|c|}{} \\
\hline \multicolumn{7}{|c|}{ Yeary } \\
\hline $\mathrm{T}_{0}$ & $7.85 \times 10^{1 \mathrm{a}}$ & $1.45 \times 10^{2 \mathrm{a}, \mathrm{b}}$ & $3.05 \times 10^{2 \mathrm{~b}, \mathrm{c}}$ & $4.10 \times 10^{2 \mathrm{c}, \mathrm{d}}$ & $5.25 \times 10^{2 \mathrm{~d}}$ & $7.00 \times 10^{2 \mathrm{e}}$ & $9.55 \times 10^{2 \mathrm{f}}$ \\
\hline $\mathrm{T}_{1}$ & $1.15 \times 10^{2 \mathrm{a}}$ & $1.85 \times 10^{2 \mathrm{a}, \mathrm{b}}$ & $3.55 \times 10^{2 \mathrm{~b}, \mathrm{c}}$ & $4.90 \times 10^{2 \mathrm{c}}$ & $6.95 \times 10^{2 \mathrm{~d}}$ & $9.20 \times 10^{2 \mathrm{e}}$ & $1.15 \times 10^{3 \mathrm{f}}$ \\
\hline $\mathrm{T}_{2}$ & $1.45 \times 10^{2 \mathrm{a}}$ & $2.05 \times 10^{2 \mathrm{a}}$ & $4.60 \times 10^{2 \mathrm{~b}}$ & $5.30 \times 10^{2 \mathrm{~b}}$ & $7.45 \times 10^{2 \mathrm{c}}$ & $1.35 \times 10^{3 \mathrm{~d}}$ & $1.45 \times 10^{3 \mathrm{~d}}$ \\
\hline $\mathrm{T}_{3}$ & $1.60 \times 10^{2 \mathrm{a}}$ & $2.25 \times 10^{2 \mathrm{a}}$ & $3.80 \times 10^{2 \mathrm{~b}}$ & $5.40 \times 10^{2 \mathrm{c}}$ & $9.45 \times 10^{2 \mathrm{~d}}$ & $1.75 \times 10^{3 \mathrm{e}}$ & $2.05 \times 10^{3 \mathrm{f}}$ \\
\hline $\mathrm{T}_{4}$ & $1.90 \times 10^{2 \mathrm{a}}$ & $2.30 \times 10^{2 \mathrm{a}}$ & $4.25 \times 10^{2 \mathrm{~b}}$ & $5.40 \times 10^{2 \mathrm{~b}}$ & $1.05 \times 10^{3 \mathrm{c}}$ & $2.05 \times 10^{3 \mathrm{~d}}$ & $2.45 \times 10^{3 \mathrm{e}}$ \\
\hline
\end{tabular}

${ }^{1}$ Abbreviations: See Table 1 .

this study, the variation of the APC and YMC of biscuit samples at the beginning and during threemonth storage period were compared as shown in the Table 7. The data suggest that APC of all samples exceeded the limit after four weeks of storage. Further, YMC data show that $10 \%$ DCF fortified sample exceeded the limit after ten weeks of storage while the $40 \%$ DCF fortified sample exceeded the limit after six weeks of storage and samples having $20 \%$ and $30 \%$ DCF fortification exceeded the limit after eight weeks of storage. This clearly shows that there is a gradual decrease in shelf life of biscuits with the increasing level of DCF fortification.

\section{Conclusions}

This study demonstrated the effect of substitution of wheat flour with defatted coconut flour on the quality of the fibre-enriched biscuits. The results showed that there was no significant difference between the control and the DCF substituted biscuit samples with respect to taste, texture, and overall acceptability up to

the level of $40 \%$ substitution. The increasing level of substitution seemed to increase the moisture, fat and protein contents of the biscuit samples significantly $(\mathrm{p}<0.001)$. With the increasing fat component, the proportion of the MCFA also had gone up. The storage study showed that there was a gradual decrease in shelf life of biscuits with the increasing level of DCF fortification. However, with regard to the microbiological parameters, there was a gradual decrease in shelf life of biscuits with the increasing level of DCF fortification.

\section{Acknowledgement}

Financial support from coconut CESS fund is acknowledged. Authors wish to express their gratitude to Dr. C. Jayasekera, Director, Coconut Research Institute of Sri Lanka for the approval granted for this publication.

\section{References}

AOAC 1999. Official Methods of Analysis, 16th Edn. Association of Official Analytical Chemists, Washington DC.

AOCS 1987. Official and Tentative Methods of the American Oil Chemists' Society. $3^{\text {rd }}$ edn., Champaign, IL: American Oil Chemists' Society.

Arancon, R.N. 1999. Coconut flour, Cocoinfo International 6: 8-10.

Awasthi, P. and Yadav, M.C. 2000. Effect of incorporation of liquid dairy by-products on chemical characteristics of soy- 
fortified biscuits, J. Food Sci. Technol., 37: 158-161.

Baensch, W., Yalegama, C. and Jayasundera, J. M. M. A. 2004. New technologies of coconut processing- part I: Process for production of virgin coconut oil and low fat / high protein coconut flour from coconut kernel, pp. 261-269, In Proceeding II of the International Coconut Conference2004, T.S.G. Peiris and C.S. Ranasinghe, (Eds.) Coconut Research Institute of Sri Lanka, Lunuwila.

Bemiller, J.N and Low, N.H. 1998. Carbohydrate Analysis, pp.172-173. In: Food Analysis Part II , S. S. Nielson (Ed.), Aspen Publishers, Gathersburg, Maryland.

Banzon, J.A., and Valesco, J.R. 1982. Coconut flour, pp. 227-238, In: Coconut Production and Utilization, Philippines Coconut Research and Development Foundation Inc., Philippines.

BIS 1974. Specification for Protein-rich biscuits, IS 7487. Indian Standards Institution, New Delhi.

Chavan, J.K. and Kadam, S.S. 1999. Nutritional enrichment of bakery products by supplementation with non-wheat foods. Crit. Rev. Fd Sci. Nut. 33: 189-226.

de Man, J. M. 1990. Carbohydrates, pp. 143-182. In: Principles of Food Chemistry, $2^{\text {nd }}$ edn., Van Nostrand Reinhold, New York.

Leelavathi, K. and Rao, P.H. 1993. Development of high fiber biscuits using wheat bran, $J$. Food Sci. Technol. 30: 187-190.

Marikkar, J.M.N., Jayasundera, J.M.M.A., Fernando, S.R. and Peiris. T.S.G. 2006. Fortification of coconut oil with sesame oil through micro expeller extraction process. Cord 22: 15-22.

Mbofung, C.M.F., Silou, T., and Mouragadja, I. 2002. Chemical characterization of safou
(Dacryodes edulis) and evaluation of its potential as an ingredient in nutritious biscuits, Forest, Trees and Livelihood, 12: 105-117.

Ong, A.S.H., Choo, Y.M., and Ooi, C.K. 1995. Developments in palm oil, pp. 153-191. In: Developments in Oils and Fats, R. J. Hamilton (Ed.), Blackie Academic \& Professional, Glasgow.

Pearson, D., 1973. pp.48-57. Laboratory techniques in food analysis, The Butterworth Group, London, U.K.

PORIM Test Method, 1995, pp. 72-100. Palm Oil Research Institute of Malaysia, Ministry of Primary Industries, Malaysia.

Ramaswamy, L. 2006. Preparation of coconut flour - its keeping quality and acceptability in recipes, Indian Cocon. J. 36(9): 13-16.

SAS Statistical Analysis System User's Guide: Basic Statistics 1998. SAS Institute Inc. Cary, NC.

Shapton, D.A. and Shapton, N.F. 1998. Microbiological criteria data tables, In: Principles and Practices for the Safe Processing of Foods, pp. 388-441. Woodhead Publishing Limited, Cambridge.

SLS 251:1991, Specification for biscuits, Sri Lanka Standard Institution, Colombo.

SLS 256:1991, Microbiological Test Methods, Sri Lanka Standard Institution, Colombo.

Swe, P.Z., Che Man, Y.B., and Ghazali, H.M. 1995. Composition of crystals of palm olein formed at room temperature, J. Am. Oil Chem. Soc. 72: 343-347.

Trinidad, T. P., Valdez, D. H., Loyola, A. S., Mallillin, A. C., Askali, F. C., Castillo, J. 
C., Masa, D. B. 2003. Glycaemic index of different coconut (Cocos nucifera) - flour products in normal and diabetic subjects, Brit. J. of Nutri. 90: 551-557.

USDA 2005, National Nutritional Data Base for Standard Reference, United States
Department of Agriculture, Washington D.C.

Yalegama, L.L.W.C., and Chavan, J.K. 2006. Studies on utilization of coconut flour as a source of cell wall polysaccharides, Trop. Agric. Res. 18: 126-134. 